\title{
DESAIN TATA KELOLA TEKNOLOGI INFORMASI RAMAH LINGKUNGAN BERBASIS ITIL VERSI 3 (STUDI KASUS: PUSTIPD UIN SUNAN AMPEL SURABAYA)
}

\section{FRIENDLY ENVIRONMENTALLY INFORMATION TECHNOLOGY'S DESIGN BASED ON ITIL VERSION 3}

\author{
Tsania Saraswati ${ }^{1}$, Andhy Permadi ${ }^{2}$, Indri Sudanawati Rozas ${ }^{3}$ \\ ${ }^{1,2,3}$ Program Studi Sistem Informasi Fakultas Sains dan Teknologi UIN Sunan Ampel Surabaya \\ Jl. Ahmad Yani No. 117 Surabaya \\ Email: ${ }^{1}$ tsaniasrwt@gmail.com, ${ }^{2}$ andhy@ uinsby.ac.id, ${ }^{3}$ indrisrozas@uinsby.ac.id \\ Diterima : 9 Juni 2018| Direvisi : 27 Juni 2018| Disetujui : 9 Agustus 2018
}

\begin{abstract}
Information Technology Center and Data Centre or PUSTIPD is a work unit that handles Information Technology at Sunan Ampel State Islamic University of Surabaya. However, any job performed by the work unit has not been regulated in the Standard Operating Procedure or known as SOP. For this reason, this paper was made to design environmentally information technology based on ITIL Version 3 's standards by discussing more about the domain service operation by taking a friendly environmentally concept. The results obtained from the domain service operation calculation are: nine sub processes with a weight of 12 and, one sub process with a weight of 16. One sub-process with the highest weight is facilities and data center management. The creation of environmentally designs according with the Service Operation domain has sub process facilities and data center management which include 9 main facilities management components and 7 key data center management factors, of which 6 are taken because they have a green concept.
\end{abstract}

Keywords: facilities and data center management, IT Governance, service operation ITIL version 3

\section{Abstrak}

Pusat Teknologi Informasi dan Pangkalan Data atau PUSTIPD merupakan unit kerja yang menangani tentang Teknologi Informasi di UIN Sunan Ampel Surabaya. Namun setiap pekerjaan yang dilakukan oleh unit kerja tersebut belum diatur dalam Standar Operasional Prosedur atau yang dikenal dengan SOP. Untuk itu, makalah ini dibuat untuk membuat desain tata kelola teknologi informasi berdasarkan standart ITIL Versi 3 dengan membahas lebih lanjut tentang domain service operation dengan mengambil konsep ramah lingkungan. Hasil yang didapat dari perhitungan domain service operation yaitu: sembilan sub proses dengan bobot 12 dan, satu sub proses dengan bobot 16. Satu sub proses dengan bobot tertinggi tersebut yaitu facilities and data centre management. Pembuatan desain tata kelola yang sudah sesuai dengan domain Service Operation memiliki sub proses facilities and data centre management yang didalamnya menyebutkan 9 komponen utama facilities management dan 7 faktor kunci data centre management, yang 6 diantaranya diambil karena memiliki konsep green.

Kata Kunci: facilities and data centre management, tata kelola TI, service operation ITIL versi 3

\section{PENDAHULUAN}

Universitas Islam Negeri (UIN) Sunan Ampel Surabaya telah berubah nama yang sebelumnya dikenal dengan nama Intitut Agama Islam Negeri (IAIN) Sunan Ampel Surabaya. Perubahan dari IAIN ke UIN membuat seluruh tata kelola didalam instasi milik Pemerintah yang bergerak dibidang pendidikan tersebut juga ikut berubah, salah satunya adalah tata kelola teknologi informasinya. Tata kelola TI berfungsi untuk membuat aturan penggunaan dengan fokus pada teknologi informasi dan manajemen kerja beserta risikonya.
UIN Sunan Ampel Surabaya memiliki beberapa unit kerja, yakni salah satunya adalah Pusat Teknologi Informasi dan Pangkalan Data atau disebut dengan PUSTIPD. Peran penting unit kerja PUSTIPD di UIN Sunan Ampel Surabaya adalah mengatur segala sesuatu mengenai teknologi informasi dan mengolah data yang dibutuhkan oleh Universitas agar menjadi sebuah informasi yang akurat (Profil PUSTIPD). Peran penting yang diemban oleh unit kerja PUSTIPD seharusnya telah diatur dalam Standart Operasional Prosedur (SOP). Namun nyatanya SOP yang dikeluarkan pada Tahun 2015 dan disahkan oleh pihak LPM tersebut 
belum menjelaskan lebih merinci tentang aturan kerja yang harus dilakukan di unit PUSTIPD. Dengan adanya tata kelola teknologi informasi yang sesuai, diharapkan dapat menjadi sebuah acuan standar operasional prosedur (SOP) dalam pemeliharaan teknologi informasi yang mengharuskan bagi pihak pengelola maupun pengguna untuk tetap menjaga aset-aset yang dimiliki UIN Sunan Ampel Surabaya.

Selain keputusan SOP tersebut, telah disebutkan oleh Undang-Undang Republik Indonesia Nomor 32 Tahun 2009 Tentang Perlindungan dan Pengelolaan Lingkungan Hidup juga diatur pengoperasian yang tidak merusak lingkungan dalam jangka panjang. Hasil keputusan pemerintah tentang Undang-Undang Republik Indonesia telah menetapkan bahwa masyarakat berhak mendapatkan kebersihan lingkungan dengan upaya menjaga lingkungan tersebut.

Pada penelitian-penelitian terdahulu terdapat beberapa judul yang juga menggunakan framework ITIL Versi 3 namun dengan domain yang berbeda. Hasil akhir dari pembuatan desain tata kelola teknologi informasi ini berupa dokumen SOP (Standar Operasional Prosedur) sesuai dengan acuan dari ITIL Versi 3 (Maita \& Akmal, 2016). Isi dari dokumen tersebut dapat berupa beberapa kebijakan-kebijakan tata kelola teknologi informasi yang telah sesuai dengan prosedur yang ada dalam ITIL Versi 3 dengan domain service operation (Aisha, Wardani, \& Ramadani, 2016).

Sehingga dalam pembahasan ini akan dilakukan aktivitas pembuatan desain tata kelola teknologi informasi dengan standart framework ITIL Versi 3 yang berfokus pada domain service operation, dan tidak lupa memasukkan beberapa konsep green service operation menggunakan studi kasus laboratorium Integrasi pada UIN Sunan Ampel Surabaya.

\section{METODE}

Kerangka kerja yang merupakan langkahlangkah yang dikerjakan saat penelitian untuk membantu pekerjaan atau memecahkan masalah agar lebih terstuktur. Kerangka kerja juga digunakan sebagai salah satu perlakuan terhadap suatu konsep dengan kemungkinan berbagai jenis atau proses bisnis (Islamiah, 2014). Sehingga pada pembuatan kerangka kerja yang kematangan dalam melakukan apa yang diharapkan dan pemberian penilaian kemampuan dibutuhkan sebuah Road map. Gambar 1 berikut merupakan road map yang dijadikan sebagai acuan oleh peneliti pada pembuatan kerangka kerja.

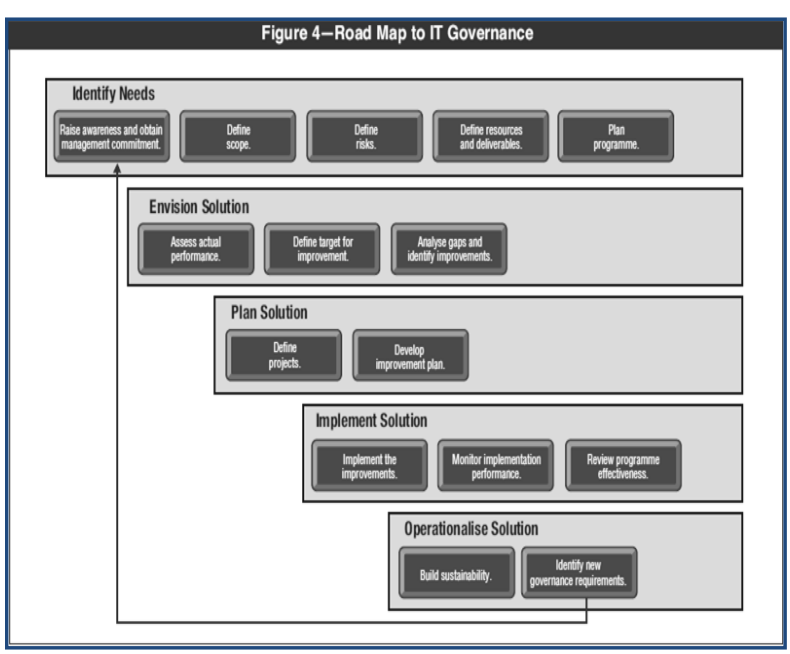

Gambar 1.IT Governance road map (Intitute, 2007)

Kerangka kerja berikut merupakan tahapan yang dilakukan untuk tahapan penelitian. Sesuai dengan Gambar 2 sebagaimana berikut penelitian ini dilakukan dengan empat tahap, yaitu:

1. Identifikasi kebutuhan yang dijabarkan lagi dengan studi literatur, studi lapangan, dan analisis kondisi existing.

2. Menyusun kebutuhan yang dijabarkan lagi dengan tiga pengerjaan yang dilakukan secara bersamaan: perhitungan kinerja, definisi target, dan analisis gap dan identifikasi kemajuan.

3. Desain tata kelola teknologi informasi, dan

4. Menguji desain yang menggunakan dua cara: credibility dan confirmability.

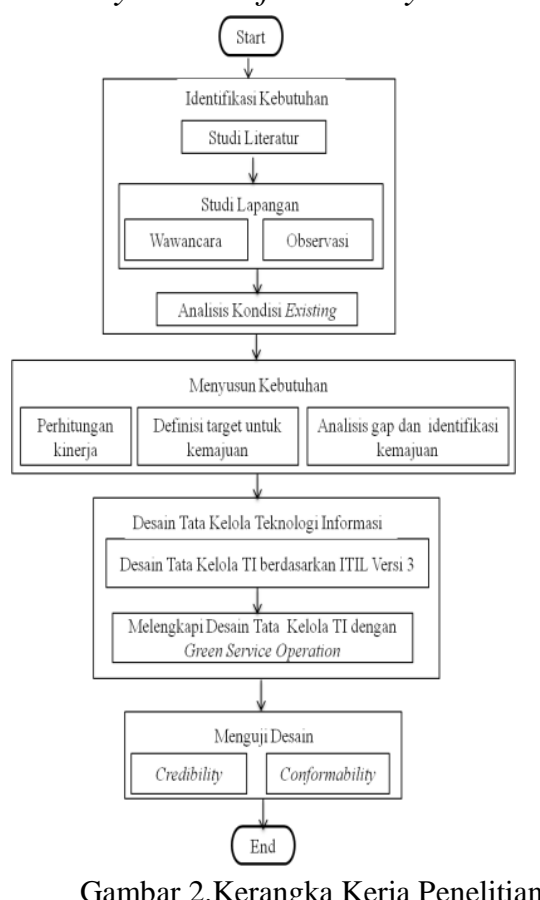

Gambar 2.Kerangka Kerja Penelitian 
Keempat tahap tersebut, penelitian ini dilakukan pada unit kerja PUSTIPD UIN Sunan Ampel Surabaya, dan waktu yang dibutuhkan dalam pengerjaan penelitian kurang lebih 3 bulan. Selanjutnya akan dipaparkan lebih rinci pada hasil dan pembahasan.

\section{HASIL DAN PEMBAHASAN}

Dalam pembuatan desain tata kelola teknologi informasi terdapat beberapa tahapan yang harus dilakukan. Tahapan tersebut telah disebutkan pada metodologi penelitian diatas (Gambar 2), berikut adalah pembahasan lebih lanjut dari tahapan tersebut.

\section{Identifikasi Kebutuhan}

Dalam identifikasi kebutuhan ini, dilakukan beberapa proses yang menghasilkan data awal. Data tersebut merupakan keadaan awal teknologi informasi yang terdapat pada lingkungan UIN Sunan Ampel Surabaya yang dapat disebut existing control. Berikut adalah beberapa proses yang dilakukan pada tahap identifikasi kebutuhan adalah studi literatur, studi lapangan dan wawancara.

Proses awal wawancara adalah menyusun tools yang didalamnya terdapat dua bagian, yaitu bagian yang berisi dari Service Operation pada ITIL berkaitan dengan proses, sub proses, dan penjelasan masing-masing sub prosesnya. Sedangkan variabel-variabel yang digunakan berkaitan dengan empat jenis, yaitu:

1. Existing control: kondisi TI saat ini yang ada di PUSTIPD.

2. Control needed: pencapaian TI seperti apa yang diinginkan oleh PUSTIPD.

3. Impact to Organization: prioritas utama yang dimiliki dalam organisasi.

4. Impact to Environment: dampak pada lingkungan atau yang berkaitan dengan green.

Fase wawancara dilakukan kepada pihak

UIN Sunan Ampel Surabaya yang memiliki wewenang atau paham dengan keadaan teknologi informasi, yiatu unit kerja PUSTIPD. Dengan melakukan 2 sesi tatap muka, masing-masing dua puluh (20) pertanyaan dan dilanjutkan dengan sembilan belas (19) pertanyaan berdasarkan dengan proses Service Operation milik ITIL Versi 3.

\section{Observasi}

Metode observasi merupakan koreksi ulang data dari hasil metode wawancara sebelumnya.
Hasil observasi terdapat beberapa data berupa angka yang diberikan oleh narasumber tidak sesuai dengan keadaan di lapangan. Sehingga terjadi evidence-based terhadap beberapa nilai pada kolom existing control sesuai hasil pengamatan dan mencocokkan kembali antara kondisi lapangan dengan data-data yang diberikan. Evidence-based merupakan keputusan yang diambil dengan kualitas terbaik yang digabungkan dari pemikiran yang kritis dan bukti-bukti yang tersedia dari pengamatan kerja sehari-hari dan mengevaluasi bukti-bukti yang ada di tangan mereka (Barends, Rousseau, \& Briner, 2014).

Tabel 1 dan Tabel 2 berikut adalah contoh dari data asli dan data yang sudah dilakukan perubahan nilai pada existing control.

Tabel 1.

Contoh Data Sebelum Evidence-based

\begin{tabular}{|c|c|c|c|c|c|c|}
\hline $\begin{array}{l}\mathbf{N} \\
\mathbf{o}\end{array}$ & Process & $\begin{array}{c}\text { Sub } \\
\text { Process }\end{array}$ & $\begin{array}{c}\text { Existi } \\
\text { ng } \\
\text { Contr } \\
\text { ol } \\
\end{array}$ & $\begin{array}{c}\text { Contro } \\
\text { l's } \\
\text { needed }\end{array}$ & $\begin{array}{c}\text { Impact to } \\
\text { Organizat } \\
\text { ion }\end{array}$ & $\begin{array}{c}\text { Impact to } \\
\text { Environt } \\
\text { ment }\end{array}$ \\
\hline 3 & $\begin{array}{c}4 . \\
\text { Service } \\
\text { Operati } \\
\text { on } \\
\text { Process } \\
\text { es }\end{array}$ & $\begin{array}{c}4.3 \\
\text { Request } \\
\text { Fulfillm } \\
\text { ent }\end{array}$ & 3 & 2 & 3 & 2 \\
\hline
\end{tabular}

Tabel 2.

Contoh Data Setelah Evidence-based

\begin{tabular}{|c|c|c|c|c|c|c|}
\hline $\begin{array}{l}\mathbf{N} \\
\mathbf{0}\end{array}$ & Process & $\begin{array}{c}\text { Sub } \\
\text { Process }\end{array}$ & $\begin{array}{c}\text { Eks } \\
\text { istin } \\
g \\
\text { Con } \\
\text { trol }\end{array}$ & $\begin{array}{c}\text { Con } \\
\text { trol' } \\
s \\
\text { nee } \\
\text { ded }\end{array}$ & $\begin{array}{c}\text { Impa } \\
\text { ct to } \\
\text { Orga } \\
\text { nizati } \\
\text { on }\end{array}$ & $\begin{array}{c}\text { Impac } \\
\text { t to } \\
\text { Envir } \\
\text { ontme } \\
\text { nt }\end{array}$ \\
\hline 3 & $\begin{array}{c}4 . \\
\text { Service } \\
\text { Operation } \\
\text { Processes }\end{array}$ & $\begin{array}{c}4.3 \\
\text { Request } \\
\text { Fulfillmen } \\
t\end{array}$ & 2 & 2 & 3 & 2 \\
\hline
\end{tabular}

Analisis Kondisi Eksisting

Analisis kondisi existing adalah hitung pengurangan yang hasilnya berupa control's gap. Jika dirumuskan seperti pada persamaan 1 berikut:

Control's Gap = Control's needed - Existing control

Persamaan 1....... Rumus Control's Gap

Kemudian dilanjutkan dengan hitung perkalian yang hasilnya terdapat pada kolom weight. Jika dirumuskan, maka seperti pada persamaan 2 berikut: 
Persamaan 2....... Rumus Weight

\section{Weight = Control's Gap *Impact to Organization * Impact to Environtment}

Variabel existing control, dikutip sesuai aturan dokumen CMMI-SVC yang disebutkan dan dijelaskan berada dalam tingkat level berapakah kondisi existing. Berikut penjelasan level existing control ada 5 yaitu (Services, 2010):

1. Level 1 disebut dengan initial

2. Level 2 disebut dengan managed

3. Level 3 disebut dengan defined

4. Level 4 disebut dengan quantitatively managed

5. Dan level 5 disebut dengan optimizing.

Selanjutnya variabel control's needed, disesuaikan dari beberapa dokumen manajemen risiko. Sehingga pemberian penilaian dan penjelasan atau spesifikasi yang sama persis sesuai penilaian dalam manajemen risiko (Tjok, 2008). Tabel 3 berikut merupakan penilaian dan spesifikasi control's needed.

Tabel 3.

Penilaian dan spesifikasi control's needed

\begin{tabular}{cc}
\hline Level & Spesifikasi \\
\hline Level 1 & Tidak ada \\
Level 2 & Sangat rendah \\
Level 3 & Rendah \\
Level 4 & Tinggi \\
Level 5 & Sangat Tinggi \\
\hline
\end{tabular}

Kemudian variabel impact to organization dan impact to environtment, menentukan tingkatan penilaian juga berdasarkan dalam manajemen risiko. Sehingga pemberian nilai menggunakan penilaian dan penjelasan atau spesifikasi yang sama persis sesuai penilaian dalam manajemen risiko (Tjok, 2008). Tabel 4 berikut merupakan penilaian dan spesifikasinya.

Tabel 4.

Penilaian dan spesifikasi impact to organization dan environtment

\begin{tabular}{lll}
\hline \multicolumn{1}{c}{ Needed } & \multicolumn{1}{c}{ Level } & \multicolumn{1}{c}{ Spesifikasi } \\
\hline $\mathbf{1}$ (Low) & 1: Rendah & Tidak butuh \\
$\mathbf{2}$ (Medium) & 2: Sedang & Butuh \\
$\mathbf{3}$ (High) & 3: Tinggi & Sangat butuh \\
\hline
\end{tabular}

Sebagaimana dengan rumus dan langkah perhitungannya maka dari masing-masing penjelasan dan spesifikasi keempat variabel dilakukan perhitungan dengan hasil sebagai berikut: Hasil dari tiga puluh sembilan (39) sub proses perhitungan yang ditunjukkan, terdapat sepuluh
(10) sub proses yang memiliki weight tertinggi yaitu 16 dan 12. Namun salah satu weight dengan nilai 16 yaitu Problem Management jika dibandingkan dengan salah satu weight yang sama dinyatakan tidak dapat ditindak lanjuti sebab memiliki beberapa justifikasi. Justifikasi tersebut berupa:

1. Nilai impact to environtmentnya dibawah dari salah satu weight 16 lainnya.

2. Pengerjaan dari sub proses problem management tersebut tidak dapat dilakukan hanya dengan satu komponen ITIL saja.

Sehingga sisa dari sembilan (9) sub proses tersebut merupakan sub proses yang akan ditindak lanjuti sesuai tahapan selanjutnya untuk pembuatan tata kelola teknologi informasi sesuai dengan Service Operation dalam framework ITIL Versi 3.

\section{Menyusun Kebutuhan}

Dalam menyusun kebutuhan, terdapat tiga kategori yang dapat dikerjakan secara bersamaan atau dengan jarak waktu yang sedikit. Berikut adalah penjelasan yang lebih mendetail dari tiga kategori tentang tahap menyusun kebutuhan.

1. Perhitungan kinerja: melakukan sorting pada kolom existing control dengan mengurutkan dari yang terbesar ke yang terkecil.

2. Definisi target: melakukan sorting pada kolom control needed dengan mengurutkan dari yang terbesar ke yang terkecil. Dimana definisi target adalah pencapaian yang ingin digapai oleh unit PUSTIPD.

3. Analisis gap dan identifikasi kemajuan: analisis gap didapatkan saat melakukan sorting pada kolom control gap. identifikasi kebutuhan didapatkan saat melakukan sorting pada kolom weight, keduanya di urutkan dari yang terbesar ke yang terkecil.

Dari hasil sorting ketiga kategori tersebut didapatkan sembilan proses dengan weight tertinggi yang dapat di lihat pada tabel berikut.

Tabel 5.

Sembilan Proses weight tertinggi

\begin{tabular}{|c|c|c|c|c|c|c|c|}
\hline Process & $\begin{array}{c}\text { Sub } \\
\text { Process }\end{array}$ & $\begin{array}{c}\text { Eksi } \\
\text { sting } \\
\text { Cont } \\
\text { rol }\end{array}$ & $\begin{array}{l}\text { Co } \\
\text { ntr } \\
\text { ol's } \\
\text { nee } \\
\text { ded }\end{array}$ & $\begin{array}{l}\text { Cont } \\
\text { rol's } \\
\text { Gap }\end{array}$ & $\begin{array}{l}\text { Im } \\
\text { pac } \\
\text { t to } \\
\text { Org } \\
\text { ani } \\
\text { zati } \\
\text { on }\end{array}$ & $\begin{array}{c}\text { Imp } \\
\text { act } \\
\text { to } \\
\text { Env } \\
\text { iro } \\
\text { ntm } \\
\text { ent }\end{array}$ & Weight \\
\hline & $\begin{array}{c}5.12 \\
\text { Facilities } \\
\text { and Data } \\
\text { Centre } \\
\text { Manageme } \\
n t\end{array}$ & 2 & 3 & 1 & 4 & 4 & 16 \\
\hline
\end{tabular}




\begin{tabular}{|c|c|c|c|c|c|c|c|}
\hline & $\begin{array}{c}9.3 \\
\text { Risks }\end{array}$ & 2 & 3 & 1 & 4 & 3 & 12 \\
\hline $\begin{array}{c}7 . \\
\text { Technology } \\
\text { consider } \\
\text { ations }\end{array}$ & $\begin{array}{c}7.1 \text { Generic } \\
\text { requiremen } \\
t s\end{array}$ & 2 & 3 & 1 & 4 & 3 & 12 \\
\hline \multirow{6}{*}{$\begin{array}{c}6 . \\
\text { Organizing } \\
\text { for Service } \\
\text { Operation }\end{array}$} & $\begin{array}{c}6.4 \\
\text { Application } \\
\text { Management }\end{array}$ & 2 & 3 & 1 & 4 & 3 & 12 \\
\hline & $\begin{array}{c}6.2 \\
\text { Technical } \\
\text { Manageme } \\
n t\end{array}$ & 2 & 3 & 1 & 4 & 3 & 12 \\
\hline & $\begin{array}{c}6.1 \\
\text { Service Desk }\end{array}$ & 2 & 3 & 1 & 4 & 3 & 12 \\
\hline & $\begin{array}{c}5.5 \\
\text { Network } \\
\text { Manageme } \\
n t\end{array}$ & 2 & 3 & 1 & 4 & 3 & 12 \\
\hline & $\begin{array}{c}5.4 \\
\text { Server } \\
\text { Manageme } \\
\text { nt and } \\
\text { Support }\end{array}$ & 2 & 3 & 1 & 4 & 3 & 12 \\
\hline & $\begin{array}{c}4.2 \text { Incident } \\
\text { Manageme } \\
n t\end{array}$ & 2 & 3 & 1 & 4 & 3 & 12 \\
\hline
\end{tabular}

Pemilahan terhadap proses desain tata kelola teknologi informasi ITIL Versi 3 seperti pada Tabel 6 diatas. Tabel 6 tersebut menujukkan sembilan proses dengan delapan proses weight 12 dan satu proses weight 16 . Weight tertinggi tersebut yaitu Facilities and Data Centre Management yang akan dilanjutkan untuk pembuatan desain tata kelola TI nya.

Desain Tata kelola Teknologi Informasi Facilities and Data Centre Management berbasis ITIL versi 3

Desain Tata kelola Teknologi Informasi yang dibuat berdasarkan terpilihnya proses dengan nilai weight tertinggi. Desain tersebut disesuaikan dengan apa yang sudah ada pada Service Operation milik ITIL versi 3 sebagaimana pada gambar 3 berikut:

\subsection{Facilities and Data Centre Management}

Facilities Management refers to the management of the physical environment of IT Operations, usually located in Data Centres or computer rooms. This is a vast and complex area and this publication will provide an overview of its key role an activities. A more detailed overview is contained in Appendix E.

In many respects Facilities Management could be viewed as a function in its own right. However, because this publication is focused on where IT Operations are housed, it will cover Facilities Management specifically as it relates to the management of Data Centres and as a subset of the IT Operations Management function.

Gambar 3. Facilities and Data Centre Management

Dalam ITIL disebutkan terdapat sembilan komponen utama yang mengatur atau memanajemen fasilitas utama sebagaimana Gambar 9 berikut:
The main components of Facilities Management are as follows:

- Building Management, which refers to the maintenance and upkeep of the buildings that house the IT staff and Data Centre. Typical activities include cleaning, waste disposal, parking management and access cont - Equipment Hosting, which ensures that all special requirements are provided for the physical housing of equipment and the teams that support them

- Power Management, which refers to managing the sourcing and utilization of power sources that are used to keep the facility functional. This definition of Power Management has a number of implications, which are discussed in Appendix E. Note that information about power utilization is important for planning the capacily of both new sevvices and new buildings

- Environmental Conditioning and Alert Systems, which include the specification, maintenance and monitoring of systems such as smoke detection and fire suppression, water, heating and cooling systems, etc.

- Safety is concerned with compliance to all legislation, standards and policies relative to the safety of employees

- Physical Access Control refers to ensuring that the facility is only accessed by authorized personnel and that any unauthorized access is detected and managed. This is discussed in more detail in Appendix $F$

- Shipping and Receiving refers to the management of all equipment, fumiture, mail, etc. that leaves or enters the building. It ensures that only appropriate items are entering or leaving the building and that they are routed to the correct party

- Involvement in Contract Management of the various suppliers and service providers involved in the facility

- Maintenance refers to regular, scheduled upkeep of the facility, as well as the detection and resolution of problems with the facility.

Gambar 4. Komponen Utama Facilities and Data Centre Management

Selain tentang fasilitas utama yang telah diatur, ITIL juga menyatakan ada tujuh kunci faktor tentang mengatur manajemen pusat data. Kunci faktor yang dimaksudkan oleh ITIL adalah untuk mendukung fungsionalitas pada pusat data. Sebagaimana yang tertera pada Gambar 5, Gambar 6 dan Gambar 7 berikut:

5.12.1 Data Centre strategies
Managing a Data Centre is far more than hosting an open space where technical
groups install and manage equipment, using their own approaches and
procedures. It requires an integrated set of processes and procedures involving
all IT groups at every stage of the ITSM Lifecycle. Data Centre operations are
governed by strategic and design decisions for management and control and are
executed by operators. This requires a number of key factors to be put in place:

Gambar 5. Data centre strategies

Pengoperasian pusat data diatur oleh keputusan desain dan strategis pusat data untuk manajemen kontrol tersebut, sehingga dari tujuh pernyataan tersebut sangat perlu dan butuh untuk ditempatkan dalam stategi pusat data yang dilakukan oleh unit kerja PUSTIPD. selain itu pernyataan gambar di atas menyatakan bahwa mengelola pusat data jauh lebih dari sekedar hosting di ruangan terbuka. Perlunya pengelolaan pusat data dalam berbagai macam proses dan prosedur yang dibutuhkan yang harus dilakukan dan melibatkan semua kelompok TI (HP) (Cannon David, n.d.). 
Data Centre Automation. Specialized automation systems that reduce the need for manual operators and which monitor and track the status of the facility and all IT Operations at all times

Policy-based management, where the rules of automation and resource allocation are managed by policy, rather than having to go through complex change procedures every time processing is moved from one resource to another

Real time services 24 hours a day, 7 days a week

Standardization of equipment. This provides greater ease of management, more consistent levels of performance and a means of providing multiple services across similar technology. Standardization also reduces the variety of technical expertise required to manage equipment in the Data Centre and to provide services

SOAs, where service components can be reused, interchanged and replaced very quickly and with no impact on the business. This will make it possible for the Data Centre to be highly responsive in meeting changing business demands without having to go through lengthy and involved reengineering and re-architecting

Virtualization. This means that IT services are delivered using an everchanging set of equipment, geared to meet current demand. For example, an application may run on a dedicated device together with its database during high-demand times, but shifted to a shared device with its database on a remote device during non-peak times - all automated and automatic. This will mean even greater savings of costs as any equipment can be used at any time, without any human intervention, except to perform maintenance and replace failed equipment. The IT Infrastructure is more resilient since any component is backed up by any number of similar

Gambar 6. Kunci faktor data centre strategies

components, any of which could take over a failed component's workload automatically.

Remote monitoring, control and management equipment and systems will be essential to manage a virtualized environment, as many services will not be linked to any one specific piece of equipment.

Unified management systems have become more important as services run across multiple locations and technologies. Today it is important to define what actions need to be taken and what systems will perform that action. This means investing in solutions that will allow Infrastructure managers to simply specify what outcome is required, and allowing the management system to calculate the best combination of tools and actions to achieve the outcome.

Gambar 7. Kunci Faktor Data Centre Strategies Lanjutan

Desain Tata kelola Teknologi Informasi Facilities and Data Centre Management dengan konsep Green IT

Desain tata kelola teknologi informasi yang berfokus pada facilities and data centre management yang telah dibuat sesuai ITIL Versi 3, selanjutnya adalah memilih beberapa desain yang berkaitan dengan konsep green. Dari sembilan komponen utama manajemen fasilitas (Gambar 4) dan tujuh kunci faktor manajemen pusat data yang (Gambar 6 dan Gambar 7), terdapat enam komponen utama yang dipilih dengan konsep desain tata kelola yang berkonsep green yang selanjutnya dijelaskan lebih detail pada Tabel 7 dibawah (Saraswati, 2018). Selain itu hasil dari desain tata kelola teknologi informasi ini adalah berupa dokumen-dokumen, yang berisi tentang aturan yang seharusnya dilaksanakan oleh unit kerja PUSTIPD.

\section{Menguji Desain Tata Kelola TI}

Setelah pembuatan desain tata kelola teknologi informasi dengan fokus pada facilities and data centre management, dilakukan pengujian desain. Pengujian desain ini dilakukan dengan dua cara, yaitu credibility dan confirmabillity.

Pengujian credibility menggunakan cara membercheck kepada narasumber, dengan memastikan bahwa hasil desain tata kelola tersebut sesuai dengan data yang telah diberikan sebelumnya (Sugiyono, n.d.). Selain itu hasil dari desain tata kelola teknologi informasi Facilities and Data Centre Management, dan desain tata kelola teknologi informasi yang dilengkapi dengan konsep green dapat dinyatakan layak untuk diterapkan setelah narasumber menyetujui hasil yang telah diberikan.

Sedangkan pengujian confirmability dengan bantuan menggunakan framework lain yaitu ISO 20000. Sembilan klausul yang dimiliki ISO 20000 memiliki number checklist masing-masing. Sembilan klausul tersebut di antaranya:

1. Scope

2. Normative references

3. Terms and definitions

4. Service management system general requirements

5. Design and transition of new or changed services

6. Service delivery processes

7. Relationship processes

8. Resolution processes

9. Control processes

Pada klausul ke enam yakni Service delivery processes dengan number clause 6.6.2 yang menunjukkan bahwa keterkaitan antara ITIL dan ISO 20000 yang membahas tentang keamanan TI yang dijabarkan lebih lanjut pada framework ITIL. Berikut adalah penjabaran lebih lanjut number clause 6.6.2 ISO 20000. 
Tabel 6. Clausul ISO 20000

\begin{tabular}{|c|c|c|c|c|}
\hline $\begin{array}{c}\text { ISO } \\
\text { 20000-1:2011 } \\
\text { Clause } \\
\text { no }\end{array}$ & $\begin{array}{l}\text { Checklist } \\
\text { item no }\end{array}$ & Brief Description & $\begin{array}{c}\text { Questions- } \\
\text { (for initiallevel } \\
\text { systemimplemented }<1 \\
\text { year) }\end{array}$ & $\begin{array}{c}\text { Audit methods and Expected } \\
\text { evidences }\end{array}$ \\
\hline \multirow[t]{3}{*}{6.6 .2} & 473 & $\begin{array}{l}\text { Physical security } \\
\text { controls on } \\
\text { premises }\end{array}$ & $\begin{array}{l}\text { What are the physical } \\
\text { security controls? }\end{array}$ & $\begin{array}{l}\text { Take two area like data centre } \\
\text { and check whether physical } \\
\text { security controls are complied with }\end{array}$ \\
\hline & 474 & Security objectives & $\begin{array}{l}\text { Are these objectives for } \\
\text { IT security? }\end{array}$ & $\begin{array}{l}\text { Check whether IT security } \\
\text { objectives are understood. } \\
\text { Are they beingcommunicated? }\end{array}$ \\
\hline & 475 & $\begin{array}{l}\text { Controls on } \\
\text { external } \\
\text { organisations }\end{array}$ & $\begin{array}{l}\text { Are controls defined } \\
\text { forexternal } \\
\text { organisations who are } \\
\text { involved inservice } \\
\text { delivery? }\end{array}$ & $\begin{array}{l}\text { Choose one or twoexternal } \\
\text { organisations andlook for } \\
\text { agreements andimplementation of } \\
\text { IT security controls. }\end{array}$ \\
\hline
\end{tabular}

Adanya framework ISO 20000 dengan Clausul number 6.6.2 menunjukkan bahwa framework tersebut juga membahas tentang pelayanan teknologi informasi. Namun pada Clausul number 6.6.2 tersebut hanya difokuskan pada keamanan data centre. Sehingga dalam pengujian desain tata kelola teknologi informasi dengan menggunakan dua framework yang didalamnya menyebutkan tentang pelayanan teknologi informasi yang baik, membuktikan bahwa desain tata kelola teknologi informasi yang dibuat oleh peneliti telah sesuai.

Tabel 7.

Desain tata kelola TI yang memiliki konsep Green

\begin{tabular}{|c|c|c|}
\hline PROSES & KONSEP GREEN YANG DIINISIASI & DETAIL KONSEP \\
\hline \multirow[t]{2}{*}{ Building Management } & Kebersihan & $\begin{array}{l}\text { mencakup semua kebersihan gedung, mulai peralatan } \\
\text { sampai kondisi gedung itu sendiri }\end{array}$ \\
\hline & Pembuangan limbah & $\begin{array}{l}\text { pembuangan limbah yang dibagi menjadi } 3 \text { : } \\
\text { yang dapat di daur ulang, barang berbahaya, } \\
\text { dokumen-dokumen rahasia }\end{array}$ \\
\hline Equipment Hosting & Peralatan yang didinginkan & $\begin{array}{l}\text { fasilitas gedung menyediakan air dingin jika ada beberapa } \\
\text { peralatan yang butuh untuk didinginkan }\end{array}$ \\
\hline \multirow[t]{2}{*}{ Power Management } & Ketika daya itu akan dibutuhkan & $\begin{array}{l}\text { memastikan bahwa aliran listrik pada ruangan tertentu } \\
\text { dialiri selama } 24 \text { jam, sedangkan di ruang-ruang lainnya } \\
\text { hanya saat jam operasional kerja }\end{array}$ \\
\hline & Berapa banyak daya yang dibutuhkan & $\begin{array}{l}\text { daya tersebut disediakan sesuai dengan kebutuhan dari } \\
\text { kondisi gedung. Agar tidak membuang aliran-aliran daya } \\
\text { yang tidak perlu }\end{array}$ \\
\hline \multirow{3}{*}{$\begin{array}{l}\text { Environmental } \\
\text { Conditioning and Alert } \\
\text { Systems }\end{array}$} & Suhu & $\begin{array}{l}\text { mengatur keadaan suhu dalam ruangan atau kapan ruangan } \\
\text { tersebut dalam keadaan panas atau dingin. }\end{array}$ \\
\hline & Kelembaban & $\begin{array}{l}\text { mengatur keadaan tingkat kelembaban udara pada suatu } \\
\text { ruangan }\end{array}$ \\
\hline & Kualitas udara & $\begin{array}{l}\text { mengatur kualitas udara yang baik untuk ruangan-ruangan } \\
\text { khusus dalam gedung }\end{array}$ \\
\hline Physical Access Control & $\begin{array}{l}\text { Instalasi dan pemeliharaan perangkat } \\
\text { kontrol akses fisik Monitoring dan } \\
\text { kontrol akses ke fasilitas }\end{array}$ & $\begin{array}{l}\text { memberikan pemeliharaan dan instalasi terhadap seluruh } \\
\text { perangkat monitoring, dan juga di setiap fasilitas lainnya } \\
\text { yang ada di dalam gedung }\end{array}$ \\
\hline $\begin{array}{l}\text { Involvement in Contract } \\
\text { Management }\end{array}$ & Leasing atau pemeliharaan lingkungan & $\begin{array}{l}\text { di dalam gedung harus tersedia peralatan-peralatan yang } \\
\text { dibutuhkan. Seperti AC, alat pemadam kebakaran, } \\
\text { pendeteksian asap, dsb agar selalu sedia jika ada peringatan } \\
\text { membahayakan dari dalam gedung }\end{array}$ \\
\hline
\end{tabular}




\section{KESIMPULAN}

Dalam pembuatan desain tata kelola teknologi informasi ini diperlukan berbagai tahapan dalam pengerjaannya, mulai dari mengidentifikasi kebutuhan, menyusun kebutuhan, membuat desain tata kelola TI, hingga menguji desain tata kelola teknologi informasi. Dari berbagai tahapan tersebut tersebut diperoleh hasil angka weight tertinggi 16 yaitu: Facilities and Data Centre Management. Dari sembilan komponen utama manajemen fasilitas dan tujuh kunci faktor manajemen pusat data, terdapat enam komponen utama yang dipilih dengan konsep desain tata kelola yang berkonsep green. Proses tersebut adalah Building Management, Equipment Hosting, Power Management, Environmental Conditioning and Alert Systems, Physical Access Control,dan Involvement in Contract Management.

\section{SARAN}

Paper ini merupakan prelimenary study desain tata kelola teknologi informasi dengan mengangkat konsep ramah lingkungan di UIN Sunan Ampel Surabaya. Penelitian selanjutnya dapat menyelesaikan delapan (8) proses terpilih yang memiliki nilai weight tertinggi lainnya sesuai dengan urgent yang dibutuhkan oleh TI di unit PUSTIPD UIN Sunan Ampel Surabaya.

\section{DAFTAR PUSTAKA}

(HP), Cannon David, D. W. (HP). (n.d.). ITIL Version 3 Service Operation. ITIL Version 3 Service Operation.

Aisha, L., Wardani, K., \& Ramadani, L. (2016). Perancangan Tata Kelola Layanan Teknologi Informasi Menggunakan ITIL versi 3 Domain Service Transition Dan Service Operation Di Pemerintah Kota Bandung, 2(2).

Barends, E., Rousseau, D. M., \& Briner, R. B. (2014). Evidence-Based Management The Basic Principles.

Intitute, I. G. (2007). IT Governance Implementation Guide.

Islamiah, M. P. (2014). Tata Kelola Teknologi Informasi (It Governance) Menggunakan Framework Cobit 5 (Studi Kasus: Dewan Kehormatan Penyelenggara Pemilu (DKPP)).

Maita, I., \& Akmal, S. (2016). Analisis Tata Kelola Teknologi Informasi Dengan Best Practice Itil V3 Service Operation (Studi Kasus: Pustaka dan Arsip Kampar) 1,2. Jurnal Ilmiah Rekayasa Dan Manajemen Sistem Informasi, 2(1), 60-65.

Saraswati, T. (2018). Desain tata kelola teknologi informasi ramah lingkungan berbasis itil versi 3 (studi kasus: pustipd uin sunan ampel surabaya), 3 .

Services, C. (2010). CMMI for Services, Version 1.3 , (November).

Sugiyono, P. D. (n.d.). Metode Penelitian Kuantitatif, Kualitatif, Dan R\&D.

Tjok, R. (2008). Enterprise Resource Planning Enterprise Resource Planning. 